\title{
CONTRA GALILEOS: LA CRÍTICA NEOPLATÓNICA DE JULIANO EL APÓSTATA AL CRISTIANISMO
}

\author{
CÉSAR GUARDE PAZ \\ Nankai University (China)
}

\begin{abstract}
RESUMEN: El presente artículo explora las relaciones entre la crítica neoplatónica al cristianismo del Emperador Juliano el Apóstata y las de sus predecesores, los Christenhasser Celso y Porfirio. En la primera parte introduciremos las motivaciones que empujaron a Juliano a su apostasía de la fe cristiana así como las bases de su paganismo, construido sobre el neoplatonismo y la teúrgia oriental de Jámblico de Calcis. A continuación se sistematizarán los argumentos de su Contra Galileos, enfatizando los puntos de contacto con la tradición anticristiana precedente y resaltando el uso retórico e instrumental que el autor realiza del judaísmo.
\end{abstract}

PALABRAS CLAVE: Juliano el Apóstata, cristianismo, paganismo, neoplatonismo, judaísmo

\section{Against the Galileans: the neoplatonic critic of Julian the Apostate to Christianism}

ABSTRACT: This article explores the relations between the Neoplatonic criticism of Christian logos in Julian the Apostate and his predecessors, the Christenhasser Celsus and Porphyry. In the first part, we will introduce his motivations for apostasy from the Christian faith, as well as the foundations of his paganism, built on the Neoplatonism and Oriental theurgy of lamblichus of Calcis. Next, we will endeavor to systematize the key arguments used in his Against the Galileans, emphasizing areas of common ground between it and the previous antichristian tradition, and stressing Julian's rhetorical and instrumental use of Judaism.

KEY WORDS: Julian the Apostate, Christianity, Paganism, Neoplatonism, Judaism

«Juliano [...] maravillándose del poder de la cruz se dijo: “¿Huyeron pues los demonios de esta imagen, no soportando verla?". "No asumas esto, mi buen amigo", dijo el mago, "pues no la temieron, como vos decís, mas horrorizados ante lo que hicisteis se marcharon"».

Teodoreto, Historia Eccleasiastica, III, 3 (p. 124 Gaisford)

\section{INTRODUCCIÓN}

En los últimos años ha aumentado considerablemente el número de estudios dedicados al análisis contrastativo de materiales documentales desde los que reconstruir las complejas interacciones entre los primeros siglos de la Cristiandad y el caduco paganismo que había caracterizado al ya deteriorado Bajo Imperio Romano ${ }^{1}$. A la ho-

\footnotetext{
1 Véanse, por ejemplo, Alan Cameron: The Last Pagans of Rome, Oxford University Press, Nueva York, 2010; Robert Shorrock: The Myth of Paganism: Nonnus, Dionysus and the World of Late Antiquity, Bristol Classical Press, Londres, 2011. Sobre el origen del concepto religioso de paganus y su falsa relación con lo "rústico", cf. CAMERon, pp. 14-20. No será hasta la década de 360 que comenzará a usarse con un sentido equivalente al de gentiles, nationes o ethnici ( $v$. infra el uso que de este último término realiza Eusebio para justificar la novedad cristiana), traduciendo en ocasiones "E $\lambda \lambda \eta v \varepsilon \varsigma$. No obstante, según testimonio del Código Teodosiano su uso era todavía vulgar a principios del s. V: «gentiles, quos vulgo paganos appellant» (XVI, 5, 46).
} 
ra de sistematizar el estudio de las diferentes figuras que constituyeron la defensa del paganismo frente a la nueva religión, dos son las aproximaciones posibles, a saber: en primer lugar, partiendo de un punto de vista cronológico pueden reconocerse a su vez dos momentos clave en las invectivas anticristianas: en primer lugar, los siglos II y III vieron el nacimiento de la crítica filosófica, ilustrada por las objeciones de Celso y Porfi-

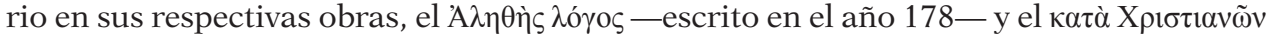
—redactada un siglo después, cerca del año $270-^{2}$. La posición del cristianismo en el s. IV, sin embargo, generó un nuevo modelo de invectiva personificado en la figura del Emperador Juliano, el Apóstata, una crítica que se diferenciará de sus predecesoras en la carencia de originalidad y fuerza discursiva ${ }^{3}$.

Si bien esta aproximación nos permite delimitar en el tiempo las reacciones paganas al cristianismo, no precisa demasiado sobre la esencia de las mismas. Así, atendiendo a su naturaleza, podemos clasificar a los paganos versados en la Antigüedad clásica en tres grupos diferenciados: los que optaron por ignorar el cristianismo en sus obras, como Libanio ${ }^{4}$; los que intentaron equiparar en valor doctrinal helenismo y cristianismo, como Temistio o Símaco ${ }^{5}$ y finalmente los que reaccionaron subversivamente contra la nueva religión, los Christenhasser: Frontón de Cirta, Luciano de Samotracia ${ }^{6}$, Celso, Porfirio y el Emperador Juliano. Mientras el primer grupo se sitúa exclusivamente a finales del s. IV, los Christenhasser se encuadran casi exclusivamente en los ss. II-III, apareciendo repentinamente como respuesta al avance cristiano. El presente estudio tiene como finalidad presentar esta línea de la Antigüedad pagana con el que fuera su último gran representante y estratega, Flavio Claudio Juliano, conocido como Juliano el Apóstata y autor de una obra titulada $\kappa \alpha \tau \grave{\alpha} \Gamma \alpha \lambda \imath \lambda \alpha i \omega v$, en su denominación latina, Contra Galilaeos.

2 Para un estudio de estos textos en castellano véase SAmuel FernÁndez: «El Discurso verídico de Celso contra los cristianos. Críticas de un pagano del siglo II a la credibilidad del cristianismo», Teología y vida, 45 (2004), pp. 238-257; JoRdi MorILlas: «La primera crítica filosófica al Cristianismo: Celso y el Alethes Logos», Daimon, 34 (2005), pp. 19-36; «Contra Christianos: la crítica filológica de Porfirio al Cristianismo», Daimon, 40 (2007), pp. 145-164.

3 Tal es la división que sigue Eustaquio Sánchez Salor: Polémica entre cristianos y paganos, Akal, Madrid, 1986, pp. 13 ss.

4 Sobre este íntimo amigo del Emperador Juliano véase PAUL PetrT: Libanius et la vie municipale à Antioche au IVe siècle après J.-C., Institut français d'archéologie de Beyrouth, París, 1955; VASILIKI LIMBERIS: "Religion" as the Cipher for Identity: The Cases of Emperor Julian, Libanius, and Gregory Nazianzus», The Harvard Theological Review, 93/4 (2000), pp. 373-400, especialmente pp. 386 ss.; EmILY WILSON: Muerte de Sócrates. Héroe, villano, charlatán, santo, Biblioteca Buridán, Barcelona, 2007, pp. 124 ss.

5 Véase Glanville Downey: "Themistius and the Defense of Hellenism in the Fourth Century», The Harvard Theological Review, 50/4 (1957), pp. 259-274; DwIGHT Nelson RoBInson: «An Analysis of the Pagan Revival of the Late Fourth Century, with Especial Reference to Symmachus», Transactions and Proceedings of the American Philological Association, 46 (1915), pp. 87-101; Francisco José Talavera Esteso: «El libro primero del "Contra Símaco" de Prudencio: Introducción y traducción española", Analecta malacitana, 5/1 (1982), pp. 129-161; José Luis Moreno Martínez: «Aurelio Prudencio y el debate sobre el altar de la Victoria», Kalakorikos, 7 (2002), pp. 79-102.

6 El mayor estudio sobre Frontón sigue siendo el de Edward Champlin: An Historical Study of Fronto of Cirta, Tesis doctoral, University of Oxford, 1976. Según Minucio Félix (Octav. 9 y 31) compuso una oratio contra los cristianos. Sobre el contenido de este texto, véase HeInRIch GotTlieb Tzschirner: Opuscula Academica, Leipzig, 1829, p. 294. Cf. M. Dовотну Brocк: Studies in Fronto and his Age, Cambridge University Press, Cambridge, 1911, pp. 93 ss. Sobre los textos satíricos de Luciano ténganse en cuenta los siguientes estudios: Adam Storey Farrar: A Critical History of Free Thought in reference to the Christian Religion, Londres, 1862, pp. 49 ss.; ERIC Francis OsBorn, Justyn Martyr, J.C.B. Mohr, Tubinga, 1973, pp. 36 ss.; RoBert E. VAn Voorst: Jesus Outside the New Testament: An Introduction to the Ancient Evidence, Wm. B. Eerdmans, Cambridge, 2000, pp. 58 ss. 


\section{CONTEXTO HISTÓRICO Y DOCTRINAL}

Hasta el s. III, momento en el que Porfirio escribe su tratado filológico contra el cristianismo, el movimiento galileo no había progresado lo suficiente como para alcanzar las capas más altas de la clase aristocrática, limitándose como secta minoritaria a extender su influencia, únicamente, sobre los estamentos medios y bajos del Imperio. La aristocracia continuaba poco impresionada ${ }^{7}$. Esta situación cambiará con el Emperador Constantino I, con quien el cristianismo se convierte en religión oficial para convivir más o menos pacíficamente con las creencias clásicas, no cristianas, hasta la toma de decisión por parte de Constancio de prohibir los sacrificios paganos en el año $341^{8}$.

A pesar de este ambiente de supuesto pacifismo y a expensas de los conflictos entre cristianos y paganos ${ }^{9}$, la escuela neoplatónica - a la que pertenecieron tanto Porfirio como Juliano- fue desde Plotino fundamentalmente anticristiana ${ }^{10}$ y no dejó de sospechar en ningún momento del modus vivendi cristiano: las críticas de Celso y Porfirio seguían, pues, plenamente vivas en el s. IV, pues no habían surgido esporádicamente sino de una raíz común incontenible, de una voluntad plenamente helena. Sin embargo, si la crítica celsiana era fundamentalmente griega antes que platónica y la de Porfirio filológica en esencia, el neoplatonismo desde el que Juliano combatirá la doctrina de los Galileos estará fuertemente impregnado por un orientalismo cuyo germen principal será Jámblico ${ }^{11}$, fundador del neoplatonismo sirio y discípulo de Porfirio. Con una Grecia empobrecida y agotada los pueblos de Egipto y Asia Menor recogen sus frutos intelectuales, disfrutando de la paz del Imperio: mientras las tradiciones de los pueblos

7 A. H. M. Jones: «The Social Background of the Struggle between Paganism and Christianity», en A. Momigliano (ed.): The Conflict between Paganism and Christianity in the Fourth Century, Clarendon Press, Oxford 1963, pp. 17-37, p. 37. Sobre la situación del debate entre cristianos y paganos en el s. III, cf. JACOB Burckhardt: Del Paganismo al Cristianismo. La Época de Constantino el Grande, tr. Eugenio Imaz, FCM, México, 1982, secciones I, V y VI; Ramsay MacMullen: Christianizing the Roman Empire, A.D. 100-400, Yale University Press, Londres, 1984, pp. 17-42; Johannes Geffcken: The Last Days of Greco-Roman Paganism, tr. Sabine MacCormack, North-Holland, Amsterdam, 1978 (edición revisada y actualizada), pp. 26-74.

8 P. De Labriolle: La Réaction Païenne. Étude sur la Polémique Antichrétienne du Ier au VIe siècle, L’Artisan du Livre, París, 1948, pp. 335-368. El Edicto de Milán, en el año 313, estableció la libertad religiosa en el Imperio con anterioridad al carácter oficial del cristianismo en el mismo.

9 Ya desde el s. I a. C. los Galileos judíos participaron activamente en revueltas antiromanas. Véase FRANCIS Loftus: "The Anti-Roman Revolts of the Jews and the Galileans», The Jewish Quarterly Review, 68/2 (1977), pp. 78-98. Muchas de las antiguas acusaciones contra los judíos se repetirán igualmente en los Christenhasser, desde Celso a Juliano. Así, Apolonio Molón (ap. Josefo, Contra Ap., 2.145 y 148) y

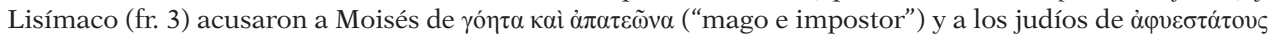

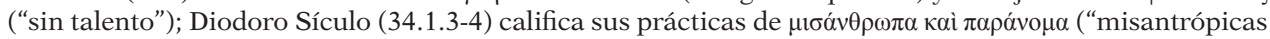
e ilegales"), cuando no de $\mu 1 \sigma o ́ \xi \varepsilon v \alpha$ ("xenófobas"). Sobre estos y otros ataques, cf. John Granger Cook: The Interpretation of the Old Testament in Greco-Roman Paganism, Mohr Siebeck, Tubinga, 2004, pp. 12-29.

10 Salvo excepciones, pues no todos los neoplatónicos fueron enemigos incondicionales del cristianismo. Así Alejandro de Licópolis, sobre el cuál véase Otтo Bardenhewer: Patrologie, Herder, Frisburgo de Brisgovia, 1894, p. 234; Geffcken, p. 74. Cf. Anthony Meredith: «Porphyry and Julian against the Christians", Aufstieg und Niedergang der römischen Welt, II/23, 1 (1980), pp. 1119-1149, p. 1120; H. LANGERBECK: "The Philosophy of Ammonius Saccas», The Journal of Hellenic Studies, vol. 77, parte 1 (1957), pp. 67-74, p. 74 .

11 Muestra admiración en su Contra Galileos (229 e). Las fuentes sobre su pensamiento han sido estudiadas en J. BouffarTigue: L'empereur Julien et la culture de son temps, Institut d'études augustiniennes, París, 1992, pp. 379-385. Cf. para una bibliografía al respecto JoHn F. Finamore: Iamblichus and the Theory of the Vehicle of the Soul, Tesis doctoral, Scholars Press, California, 1985, p. 159, nota 29. 
europeos sucumben rápidamente a la cultura latina, Asia y Egipto no sólo se resisten, sino que exportan sus nuevas creencias a un Occidente admirado ${ }^{12}$. Es aquí en donde brota el pensamiento de Juliano, bebiendo directamente de este ambiente intelectual en el que las nuevas ideas de Oriente enriquecen para unos y empobrecen para otros el paganismo heleno.

\section{JULIANO Y SU $\kappa \alpha \tau \grave{\alpha} \Gamma \alpha \lambda \imath \lambda \alpha i ́ \omega v$}

\subsection{Biografía}

Juliano nace en el año 331 en Constantinopla, hijo único de Julio Constancio con Basilina, mujer educada y devota cristiana, fallecida cuando Juliano sólo contaba con unos pocos meses de vida ${ }^{13}$. Dos hechos influyeron notablemente en su desarrollo filosófico y posterior reinado: el asesinato de la práctica totalidad de su familia más cercana a manos de su primo, Constancio II, así como la educación pagana que, en combinación con sus estudios cristianos, recibió en los primeros años de su vida.

En lo que a su formación respecta, el joven Juliano fue enviado a estudiar literatura y filosofía griegas a Nicomedia, prosiguiendo su búsqueda intelectual en Atenas y algunas ciudades de Asia Menor, en donde su amor por la cultura helena y sus grandes maestros, unido al asesinato de su familia, sembrarían en el joven Juliano la semilla de la apostasía ${ }^{14}$. En Nicomedia estudió con Eusebio y con el eunuco Mardonio, maestro de su madre Basilina, mientras en Constantinopla recibió instrucción del sofista Hecébolo. Edesio y Crisantio, discípulos de Jámblico en Pérgamo, junto al teúrgo Máximo de Éfeso completarían su educación pagana tres años después de su definitiva renuncia a la oscuridad cristiana y su conversión a los ideales paganos ${ }^{15}$. Este hecho, que tuvo lugar en Nicomedia en el año 351, no sólo redirigiría toda

12 El filólogo belga Franz Cumont, autoridad en lo que a religiones mistéricas se refiere, culpa de ello a la superioridad del pensamiento asiático, por ejemplo en Las Religiones Orientales y el Paganismo Romano. Conferencias pronunciadas en el Collège de France en 1905, trad. de José CARLos BermeJo Barrera, Akal, Madrid 1987, especialmente en pp. 172-173. Cf. WALter BURKERT: The Orientalizing Revolution: Near East Influence on Greek Culture in the Early Archaic Age, trad. al inglés del propio autor, Harvard University Press, Londres 19973, quien sostiene que este fenómeno ya provocó, un milenio atrás, el «griechisches Wunder».

13 Para una biografía completa de Juliano remitimos a las introducciones a su obra en, por ejemplo, The Works of the Emperor Julian, ed. de W.C. WRIGHT, Loeb, Londres 1962-1969, 3 vv., vol. 3, pp. VII ss. y, en castellano, el primer volumen de sus Discursos, publicado en Gredos, Madrid, 1982, con traducción de José García Blanco, pp. 7-54. El lector interesado puede recurrir a la amplia bibliografía contenida en ésta última y en la obra de Klaus Rosen: Julian: Kaiser, Gott und Christenhasser, Klett-Cotta, Stuttgart, 2006, en donde se incluyen, entre otros, los siguientes estudios biográficos: J. BIDEz: La vie de l'empereur Julien, Les Belles Lettres, París, 1930; R. Browning: The Emperor Julian, Weidenfeld and Nicolson, Londres, 1975; G. W. Bowersock: Julian the Apostate, Harvard University Press, Cambridge, 1978; PolymnIA Athanassiadi-Fowden: Julian and Hellenism: An Intellectual Biography, Routledge, Londres 1992.

14 K. F. STRoHeKer: «Das Konstantinische Jahrhundert im Lichte der Neuerscheinungen 1940-1951», Saeculum, 3 (1952), pp. 654-680, p. 676; F. DvorNIK: «The Emperor Julian's 'Reactionary' Ideas on Kingship», en K. Weitzmann (ed.): Late Classical and Mediaeval Studies in Honor of Albert Mathias Friend Jr., Princenton University Press, Princenton, 1955, pp. 71-81.

15 Sobre la educación que recibió Juliano véase, en la edición de Gredos, pp. 19-25; J.W. DonaLDSon: A History of Literature of Ancient Greece, 2 vv., Parker \& Son, Londres 1858, vol. 2, p. 304, nota 2. Según testimonio de Eunapio (Vidas, p. 437, ed. Wright) se habría iniciado también en los misterios eleusinos en su estancia en Atenas. 
su carrera política en dirección contraria a los Constantinos, sino que marcaría, adicionalmente, una ruptura vital con su familia — a la que veía como hipócritas y traidores-y sus primeros educadores, que a pesar de ser cristianos llevaban una vida tan poco digna y divina como la de los asesinos de su familia ${ }^{16}$. El paganismo, y en concreto su interpretación neoplatónica a través de la teúrgia consolidada por Jámblico, serán la respuesta de Juliano al cristianismo ${ }^{17}$, una respuesta que nace en el Emperador como responsabilidad vital a la asimilación anímica que del platonismo realizó el cristianismo alejandrino.

Con la ocasional muerte de Constancio II en Mopsucrene, cerca de Tarso, el apoyo de las tropas permite a Juliano ascender pacíficamente al poder en diciembre de 361, reemplazando rápidamente eunucos y cortesanos por sofistas y filósofos en un claro intento representacional de la República platónica ${ }^{18}$. Junto a estas reformas estatales, Juliano modificará la legislación relativa a las prácticas religiosas, reconstruyendo templos paganos, estableciendo la libertad de culto en el Imperio y reduciendo cada vez más los privilegios que su familia había otorgado a los cristianos ${ }^{19}$.

Todo este programa legislativo estaba encauzado hacia un propósito que Juliano tenía muy claro: la eliminación del cristianismo del marco estatal y la restauración de los privilegios de los paganos, unida a una libertad de culto tras la cual se vislumbraba no sólo su temprano amor por la cultura helena, sino también su resentimiento hacia una doctrina sin ley ni instrucción (paideia), tal y como había sido proclamado previamente por los acusadores Celso y Porfirio.

\subsection{Doctrina y contenido textual}

Dividiremos nuestro análisis del corpus doctrinal de Juliano en dos apartados: en esta primera parte analizaremos brevemente los pormenores doctrinales que anticipan el ataque del Apóstata a la religión cristiana como sistema nuevo, contrario incluso a los propios judíos, puestos ya en contraposición con los paganos por el pensamiento heleno precedente ${ }^{20}$. Desde este punto de vista, resulta incluso más sugerente aproximarse al modo en que se entrelazan, por un lado, la necesidad de una reforma política

16 Íbid., pp. 304-305.

17 Acerca de la conversión de Juliano véanse los testimonios de Amiano Marcelino, XXII, 5, 1; Libanio, I, p. 258 (Reiske); del mismo Juliano en su Epístola XLVII, 434 d; su hagiografía mitraica Contra el cínico Heraclio, 227 c-234 c y su Oración IV a Helios, 131 a, en donde se expresa con estas palabras: "Olvidemos aquellas tinieblas» (de la trad. de J.G. Blanco, Discursos, vol. II, ed.cit.). Cf. Sócrates, H.E., III, 3 (p. 124, Gaisford) y Juliano, Or. IV, 146 a y 157 b, para la influencia de la teúrgia de Jámblico. En castellano puede consultarse M. J. HIDALGO DE LA VEGA: «Teología política de Juliano como expresión de la controversia paganismo-cristianismo en el siglo IV», en VV. AA.: Cristianismo y aculturación en tiempos del Imperio Romano, Monografías históricas sobre la Antigüedad tardía, vol. 7, Universidad de Murcia, Murcia, 1990, pp. 179-195, pp. 181 ss.

18 Una interesante profundización en los conflictos cristianos que siguieron al ascenso al poder de Juliano puede consultarse en Joseph Torrey: General History of the Christian Religion and Church, trad. A. Neander, Crocker \& Brewster, Boston, 1854, 3 vv., vol. 2, pp. 35-66.

19 "He now regarded himself as conducting a war in the name of Hellenism», en palabras de Wright, en Wright, III, p. XVI. La intolerancia de Juliano hacia el cristianismo fue en aumento, prohibiendo el estudio de los clásicos paganos entre las familias cristianas e intentando restaurar el Templo de Jerusalén para promover las prácticas judías frente a las cristianas. Véanse Sócrates, H.E., III, 15; 21; Sozómenes, H.E., 17 ss.. Cf. Juliano, Ep. Frag., 295 c; Ep. XLI, 398 a, etc., Sozóm., H.E., V, 22.

20 Por ejemplo en Celso, V, 6, así como Granger, pp. 12-29, en nota 9. Para una introducción completa al pensamiento religioso y filosófico de Juliano, véase Rowland Smith: Julian's Gods. Religion and Philosophy in the thought and action of Julian the Apostate, Routledge, Nueva York, 1995. 
que restaurase la soberanía clásica del filósofo-rey y, por otro, la necesidad de defender al paganismo del acomodacionismo cristiano que amenazaba con asimilarlo. Es en este sentido que puede decirse que Juliano no sólo era perfectamente consciente de su papel reformador, sino que, como veremos en el apartado siguiente, sus alusiones al pueblo judío, en modo alguno exiguas, serán el arma arrojadiza con la que el Apóstata se entregará al asalto crítico de la secta de los Galileos.

El punto central de su programa político se enuncia en un pasaje de su Himno al Rey Helios, dedicado a Salustio y escrito durante las horas robadas a tres frías noches de diciembre. Aquí Juliano se identifica a sí mismo con el filósofo-rey platónico, en clara alusión a un pasaje del final de la República ${ }^{21}$ : habiendo sido su alma sembrada por Helios en una familia poderosa, cae sobre él la tarea de restaurar la hegemonía greco-

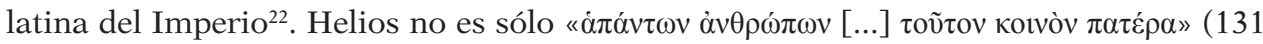
c) ${ }^{23}$, sino también protector de Roma y del modo de vida transmitido por los antiguos

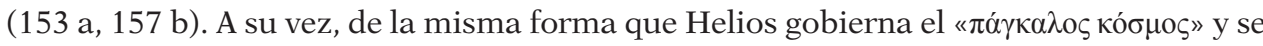
identifica con el Bien platónico, Juliano, cuya alma ha encarnado Helios en su cuerpo de Emperador, debe representar ese mismo Bien en la Tierra y traer la luz a todos los hombres, según su especie ${ }^{24}$.

Este programa político no puede prescindir, pues, de un constructo teológico de raíces paganas que, para el Apóstata, se identifica con el neoplatonismo y con la teúrgia de Jámblico, con la que pretendía iluminar el conocimiento de los antiguos dioses ${ }^{25}$ : una cosmovisión que se enorgullece en refutar una moral que al heleno le resulta antitética, de la que difiere toto caelo de la magnificencia pagana, del riguroso instinto anímicamente superior y sublime que caracterizaba, según Juliano, a todos los pueblos de la Antigüedad y al heleno por encima de todos. En un imperio carente de cohesión metafísica en el que la distancia entre la fe popular — por ejemplo, cultos a las piedras ungidas - y las mentes cultas era cada vez mayor ${ }^{26}$, el pensamiento de Juliano debe ser entendido, en palabras de Anthony Meredith, como un «alegato por la integridad de la cultura clásica» y como un ataque al pretendido matrimonio alejandrino entre platonismo y cristianismo, del que la cultura y filosofía helenas debían separarse para

21 Juliano, Discurso al Rey Helios, 131 b; Platón, República, X, 620 d.

22 Huelga decir que Juliano comprendía la civilización latina como una extensión del mundo grie-

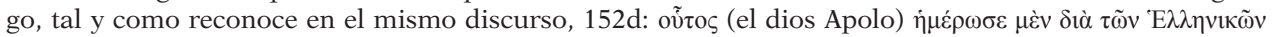

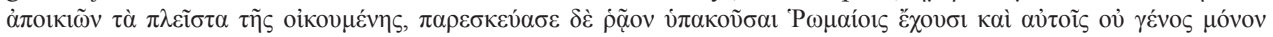

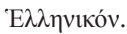

${ }_{23}$ Sobre este principio descansan sus ideas de caridad y filantropía, practicadas también por los cristianos, mas no en virtud de la humanidad común a todos sino, según Juliano, hipócritamente con la secreta intención de aumentar sus filas conduciendo a sus creyentes al ateísmo. Cf. Ep. Fr., 289 a-291 a; Ep. XXII, $130 \mathrm{~d}$.

24 Juliano cita Platón, Rep., VI, 506 d; 508 c; Ep. II, 312 e, además de un pasaje de las Enéadas de Plotino, V, 3, 13. La imagen resultante es poderosamente evocadora de la Alegoría de la Caverna y de la encarnación de Dios en Cristo.

${ }_{25}$ Sobre la teología de Juliano en relación al Himno o Discurso al Rey Helios, véase John M. Dillon: "The Theology of Julian's Hymn to King Helios», Ítaca. Quaderns Catalans de Cultura Clàssica, 14-15 (1998-1999), pp. 103-115; Emma C. Clarke, John M. Dillon y Jackson P. Hershbell: Iamblichus. On the Mysteries, Society of Biblical Literature, Atlanta, 2003, p. xxvii. (traducción ampliamente revisada de la edición francesa de Les Belles Lettres de Édouard Des Places, publicada en 1966). Las fuentes mitraicas del Himno fueron ya discutidas por Roger Beck: «Mithraism since Franz Cumont», en Hildegard TempoRINI Y Wolfgang HaAse: Aufstieg und Niedergang der römischen Welt, de Gruyter, Berlín, 1984, II.17.4, pp. 2002-2115, p. 2053.

26 Cumont, p. 172. 
evitar la influencia enfermiza y envenenadora de una moral y una doctrina contrarias a la Antigüedad, al Mundo y a lo que éste guardaba de noble ${ }^{27}$.

Conforme a esta breve exposición, cabría imaginar que Juliano desarrollaría un sistema paralelo en complejidad al de su alabado Jámblico. No obstante, el Apóstata no aspira a la originalidad ni es su intención presentar un sistema complejo o innovador. Al contrario, Juliano es ante todo un transmisor y restaurador de la tradición pagana que tiene como referentes a Plotino y, en especial, al neoplatónico y discípulo de Porfirio, el ya mencionado Jámblico de Calcis. A ellos sigue en lo que a su idea de un principio

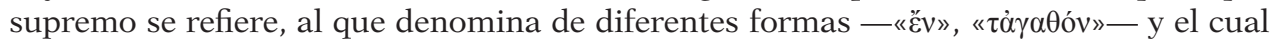
identifica, como ya se ha visto, con Helios, la divinidad que originalmente preside sobre

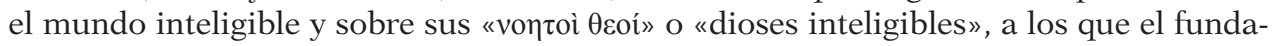

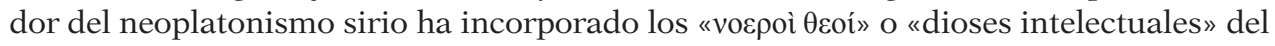
mundo intermedio. De esta forma el pensamiento de Jámblico queda reducido, a través de Juliano, a un sistema tripartito en el que coexisten tres mundos regidos por tres soles: Helios primero, su correspondiente transcendental entre los inteligibles y, finalmente, su manifestación visible, el Sol. De estas tres realidades la más importante es la intermedia, por ejercer de mediador (« $\mu \varepsilon \sigma o ́ \tau \eta \varsigma »)$ entre las dos realidades platónicas, un papel que corresponderá a Mitra ${ }^{28}$.

Cabe resaltar, ante todo, que tanto el mito de Helios como el de la Madre de los Dioses, explicados racionalmente en sus correspondientes oraciones, responden a una interpretación metafórica del mito que el neoplatonismo, frente al judeo-cristianismo, reclama: el mito como historia alegórica tras la que se esconde una enseñanza o una idea sincrética iniciática ${ }^{29}$, una idea que, aún siendo característica del neoplatonismo sirio y reflejo de la racionalización estoica, encontramos ya en Platón y su interpretación del Mito de Faetón, precisamente hijo de Helios (Tim., 22 c-d), historia a la que Juliano alude en su Oración III (208 b).

Las similitudes entre las enseñanzas neoplatónicas impregnadas de orientalismo y mitraísmo ${ }^{30}$, por un lado, y los fundamentos de la fe cristiana, por otro, hicieron pensar tempranamente en una rivalidad basada en el plagio doctrinal de los paganos, acusados de satanismo por los Padres de la Iglesia ${ }^{31}$. Pese a las semejanzas superficiales y la in-

27 Meredith, p. 1138. Cf. Contra Galileos, 229 c; Porfirio, fr. 39. Cf. E. Vacherot: Histoire Crítique de l'École d'Alexandrie , ed. de Adolf M. Hakkert, Amsterdam, 1965, 3 vv., vol. 2, pp. 120 ss..

${ }_{28}$ La idea podría ser de origen persa. Véase, además de Wright, I, pp. 349-350 (Oración IV, 133 d), los citados estudios sobre mitraísmo y teología juliana. Cf. Plutarco, Isis y Osiris, 46. A. Naville ha señalado, no sin razón, la semejanza entre esta idea y el logos cristiano, en el que Cristo es a la vez manifestación del Padre y mediador entre ambos mundos, en Julien l'Apostat. Philosophie du Polithéisme, L'Erma di Bretschneider, Roma 1972, p. 104.

29 Sobre su función didáctica, véase Or. VII, 207 a ss., 219 b, 222 c. Cf. Salustio, Sobre los Dioses y el Mundo, III-IV. Sobre su significado iniciático, Or. V, 169-170; Or. VII, 206 c; Césares, 306; Contra Galileos, 94 a.

30 Wright, I, p. 348. Cf. Hans Lawy: Chaldean Oracles and Theurgy, ed. de M. Tardieu, Études Augustiniannes, París 1978, pp. XIII y 461 ss.

31 Por ejemplo, Justino Mártir, Apología, I, 66; Dial. Typho, 70; Tertuliano, Praes., 40; etc. Sobre esta idea en la patrística véase CARSTEN COLPE: «Die Mithramysterien und die Kirchenväter», en W. DEN Boer et al. (ed.): Romanitas et Christianitas: Studia J. H. Waszink, North-Holland, Amsterdam, 1973, pp. 29-43. Cf. J.E. Renan: History of the Origin of Christianity, Mathieson, Londres, 1890, 8 vv., vol. 7, p. 331; A. Piganiol: L'Empire Chrétien, PUF, La Broché 1973, p. 131. La acusación y relación entre satanismo y paganismo también la recogerá Focio en su Biblioteca, 483b15-484b14, sobre la cual véase el estudio de este pasaje en Sabino Perea Yébenes: «Un trasfondo mithraico en los conflictos religiosos en Alejandría en tiempos del Emperador Juliano según la Vida de Atanasio en la Biblioteca de Focio», Studia historica. Historia antigua, 24 (2006), pp. 83-107. 
negable vinculación entre algunos aspectos de ambos movimientos, no debe olvidarse, como ha señalado Luther H. Martin, que "la diferencia entre la Cristiandad y el mitraísmo parece estar rodeada por la comprensión de la Cristiandad sobre el orden histórico de las cosas como una alternativa al entendimiento cósmico del paganismo", antes que una rivalidad específica entre ambas teologías ${ }^{32}$.

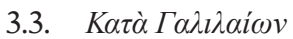

Juliano, en una epístola dirigida a Fotino, obispo de Sirmio, conservada en el Pro defensione trium Capitulorum de Facundo de Hermíone (IV, 2, Migne PL, 67, p. 621) y escrita en algún momento de su estancia en Antioquia, entre julio de 362 y marzo del año siguiente ${ }^{33}$, anuncia ya la redacción de una obra dirigida contra una «religionis agrestis», en la que pretende demostrar, en «larga y dura polémica ${ }^{34}$, que en el Antiguo Testamento no existe idea alguna que lleve al cristianismo, "pura irrisión y garrulería», por lo cual éste no tiene derecho a considerarse heredero legítimo del judaísmo. La fecha y el lugar de redacción quedan confirmados, a su vez, por el epitafio a Juliano escrito por su amigo Libanio (Or. XVIII) en el año $365^{35}$, mientras acompañaba al Emperador en su campaña de restauración del paganismo en la ciudad de Antioquía, momento en el cual escribirá también otras importante polémicas, como su Misopogon, fechada a principios de $363^{36}$.

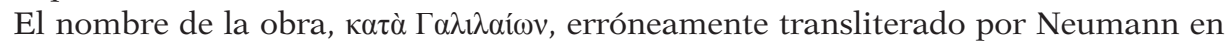

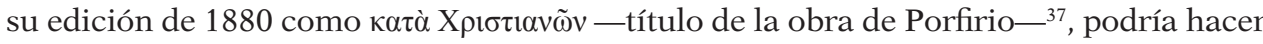
referencia, ora al carácter local de esta creencia, inspirado en los mismos Evangelios y en los Hechos de los Apóstoles ${ }^{38}$ y ya utilizado poco antes por Epícteto en su Dissertationes ab Arriano digesta (IV, 7, 6) ${ }^{39}$, ora al carácter tradicionalmente rebelde y disidente de este grupo de judíos ${ }^{40}$. Lo cierto es que esta denominación forma parte de la estrategia juliana de instrumentalización del judaísmo como arma retórica con la que enfrentarse a los cristianos. Pocos años antes el mismísimo Eusebio de Cesarea había respondido a

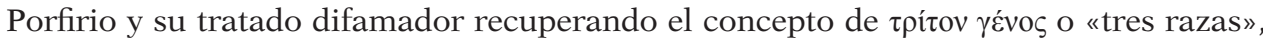

32 Luther H. Martin: «Roman Mithraism and Christianity», Numen, 36/1 (1989), pp. 2-15, p. 11.

33 Sobre la fecha de composición véase Wright, III, p. 186-187, n. 4 y p. 314. La epístola está numerada como LV en la edición inglesa de Loeb, y como 90 en las ediciones española y francesa de Gredos y Les Belles Lettres.

34 Libanio, Or. XVIII, 178. Citamos de la traducción contenida en la introducción a la edición de Gredos de Contra Galileos, p. 9.

35 Sobre la fecha de la oración de Juliano, véase la edición definitiva de R. Foerster (ed.): Libanii Opera, Teubner, Leipzig 1904, vol. 2, pp. 224, «non ita multo ante finem anni 365 orationem conscriptam esse coniecerim».

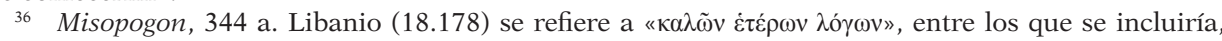
también el Himno al Rey Helios y los Césares, compuestos en diciembre.

37 El error de Neumann no se debe, como pretende Wright en su edición inglesa (III, p. 313, n. 1), a la ignorancia del texto de Gregorio Nacianceno, sino al nombre que en las fuentes se da a la invectiva de Teodoro de Mopsuesta contra la obra de Juliano, Adversus Iuliani apostatae calumnias in Christianos

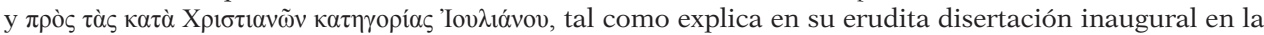
Universidad de Leipzig, en K. J. Neumann: Prolegomena in Iuliani imperatoris libros quibus impugnavit Christianos, Teubner, Leipzig 1880, pp. 23-24.

38 Por ejemplo, Hechos, 2:7. Tanto Gregorio Nacianceno (Or. III, LXXvi, 114 p. 602 Migne) como Sócrates (H.E., III, 12) nos informan de su hábito de denominar Galileos a los cristianos.

39 Stefania Scicolone: «Le accezioni dell'appellativo Galilei in Giuliano», Aevum, 56 (1982), pp. 71-80.

40 Loftus, pp. 87 ss. 
según el cual existían tres pueblos: los helenos, los judíos y los cristianos ${ }^{41}$. De esta forma los Padres de la Iglesia intentaban justificar el carácter neófito de que era acusado el

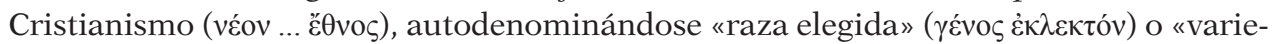
dad intermedia» que se había liberado del error de sus padres ${ }^{42}$. Los cristianos no eran sólo el nuevo pueblo elegido, sino que ya desde San Justino Mártir y la famosa Apología de Arístides constituían una «raza» diferenciada de los judíos ${ }^{43}$. De esta forma, con su negación del tercer genus, Juliano no sólo se enfrentará a la apologética cristiana ${ }^{44}$, sino que, acusando a los Galileos de ser una simple secta de los judíos, ratificará que las invectivas de sus predecesores no han sido todavía superadas.

Retornando al destino del texto, ampliamente estudiado por Neumann en su ya citada edición ${ }^{45}$, y al igual que sucediera con Celso y Porfirio, la obra de Juliano contra la secta de los Galileos también se ha perdido y su conservación, fragmentaria, se ha debido una vez más a una de las invectivas de los apologetas cristianos, el Pro Christiana Religione adversus Julianum imperatorem de Cirilo de Alejandría. Escrito en algún momento entre los años 429 y 441, es a partir de este texto que Karl J. Neumann reconstruyó su edición de 1880, basándose en la edición de Cirilo realizada por Ezechiel Spanheim (1696), de la que extrajo los fragmentos de Juliano citados por el Patriarca

${ }^{41}$ Ya en los Discursos de Pedro (ap. Clemente, Strom., vI, 5, 41), datados en la primera mitad del s. II, así como en la Epístola a Diogneto, 5, 17 (finales del s. II) y el Pseudo Bernabé (5, 7; 7,5) se encuentra in nuce esta idea. Cf. para su desarrollo Eusebio, H.E., I, 4, 2; P.E., I, 2, 1 (en donde los cristianos son denominados «variedad intermedia»); 2, 3-4; 5, 12; D.E., I, 2; Tertuliano, Ad Nationes, 1,8. La bibliografía al respecto es abundante, comenzando con el imprescindible estudio de Adolf von HaRnack: Die Mission und Ausbreitung des Christentums in den ersten drei Jahrhunderten, Hinrichs, Leipzig, 1902, 19244,2 vv., vol. 1, pp. 259-281; Domingo RAmos-Lissón: "La novità cristiana negli apologisti del II secolo», Studi e Ricerche sull'Oriente Cristiano, 15 (1992), pp. 15-24; ARYEH KofsKy: "Eusebius of Caesarea and the Christian-Jewish Polemic», en Ora Limor y Guy G. Stroumsa (eds.): Contra Iudaeos: Ancient and Medieval Polemics between Christians and Jews, J.C.B. Mohr, Tubinga, 1996, pp. 59-83 (=Id.: Eusebius of Caesarea against Paganism, Koninklijke Brill, Leiden, 2000, pp. 100 ss.); EduARD IrIcINSchI: «Good Hebrew, BAD Hebrew: Christians as Triton Genos in Eusebius' Apologetic Writings», en Sabrina Inowlocki y Claudio Zamagni, Reconsidering Eusebius. Collected Papers on Literary, Historical, and Theological Issues, Brill, Leiden, 2011, pp. 69-86.

${ }^{42}$ Respectivamente, Eusebio, H.E., 1, 4, 2; I Pe 2, 9-10; Eus., P.E., 1, 5, 12. En este último pasaje se diferencia explícitamente a los cristianos de los judíos y de los helenos con una clara alusión a Celso, al

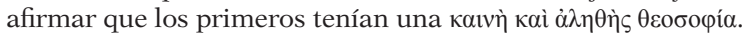

43 Just., Dial., 119, 3-6; Arístides, Apol., 2. El texto griego de éste último establece tres divisiones: paganos, judíos y cristianos, mientras la versión armenia y siríaca diferencia entre bárbaros y helenos, estableciendo, pues, cuatro geni. Sobre la superioridad de la versión siríaca véase J. R. HARRIs (ed.): The Apology of Aristides on behalf of the Christians, Cambridge University Press, 1891 (reed. Gorgias Press, 2011), pp. 67 ss. Remitimos a esta edición para una relación entre este texto y Celso, los Discursos de Pedro o Eusebio de Cesarea.

${ }_{44}$ Su conocimiento de la obra de Eusebio de Cesarea contra Porfirio parece evidente a la luz de éste y otros motivos. Juliano habría leído su crítica al neoplatónico gracias a la biblioteca de Jorge de Capadocia, que habría consultado durante su exilio en la ciudad (342-348). Jorge de Capadocia fue asesinado durante las revueltas paganas del 24 de diciembre de 361 (Sócrates, H.E., III, 2, 10; Sozómenes, H.E., V, 7, 2-4; Epifanio, Panarion, 76, 1; etc.) y su biblioteca saqueada, por lo que poco después de llegar a Antioquía Juliano redactó dos epístolas, una a Porfirio (Ep. CVI, $411 \mathrm{c}-\mathrm{d}$; Ep. 38 en la edición de Wright) y otra al prefecto egipcio Ecdicio (Ep. CVII, 377 d, 378 a-b; Ep. 23 Wright), pidiendo la recuperación de los textos filosóficos y galileanos, probablemente con la intención de documentarse para la realización de su Contra Galileos (Bidez, 1930, p. 25). Porfirio habría sido, según Wright (III, p. 74, n. 1), secretario de Jorge de Capadocia, aunque esta asunción se basa probablemente en el título de su carta contenido

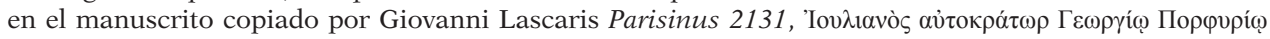

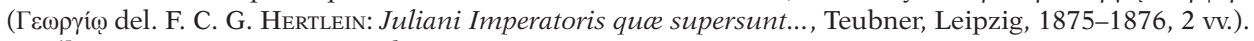

45 Neumann, op. cit., capítulo primero. 
alejandrino y añadió los comentarios de éste a pie de página ${ }^{46}$. Al igual que el texto original de Juliano, la réplica al mismo de Cirilo de Alejandría no se ha conservado íntegramente y de ella sólo nos han llegado los diez primeros libros, correspondientes

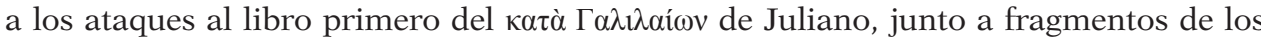
diez siguientes volúmenes en florilegia y catenae, correspondientes al segundo libro de Juliano ${ }^{47}$. En base a esto, Neumann dedujo, no sin razón, que la obra de Cirilo constaba originalmente de 30 libros, diez por cada uno de los del tratado de Juliano ${ }^{48}$, una hipótesis rechazada sin embargo por los editores modernos que argumentan que, tal vez, el Apóstata nunca terminara su obra y, por tanto, Cirilo habría escrito únicamente los veinte libros de los cuales tenemos constancia ${ }^{49}$. Sin embargo, en la dedicatoria a Teo-

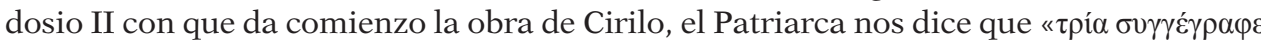
$\beta i \beta \lambda i \alpha^{50} y$, de igual forma, Libanio, presente durante la composición del tratado juliano, da a entender que su discurso contra los Galileos había sido ya terminado ${ }^{51}$.

En cualquier caso, la obra de Cirilo es la única de las muchas invectivas que en el s. V se dirigieron contra la obra de Juliano que han llegado hasta nosotros y cuya ejecución apuntaba probablemente mucho más allá de las páginas del Apóstata ${ }^{52}$. Además de las críticas que desde bien temprano Efrén de Siria y Gregorio Nacianceno ${ }^{53}$ escri-

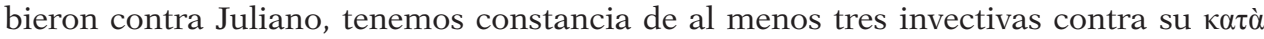

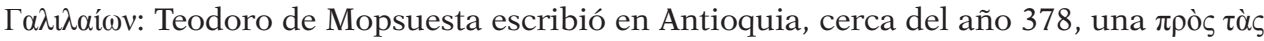

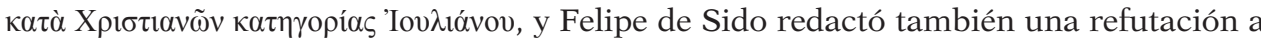

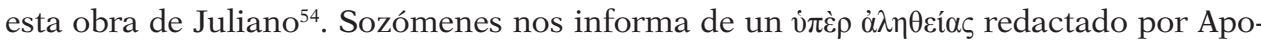
linar de Laodicea, noticia que Neumann ha rechazado acertadamente por una cuestión cronológica $^{55}$.

A pesar del gran número de ataques que se dirigieron contra su obra no parece

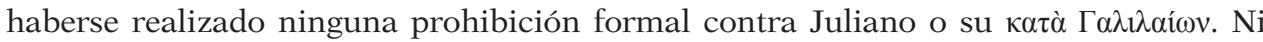

46 Sobre la problemática edición de Spanheim, véase CARLo Prato: «Ezechiele Spanheim e la fallita edizione di Giuliano Imperatore», Filología e forme letterarie, Collana, Urbino, 1987, 5 vv., vol. 5, pp. 579587. Cf. U. von Wilamowitz-Moellendorf, Geschichte de Philologie, Teubner, Leipzig 1959, p. 33, «sein Julian ist unbedeutend».

47 Cirilo, sin embargo, dice haber censurado parte de las críticas del Apóstata por considerarlas peligrosas. Cf. K. J. Neumann: Iuliani imperatoris librorum Contra Christianos quae supersunt, Leipzig 1880 p. 97, para una descripción detallada de las demás fuentes del tratado de Juliano: el comentario al Nuevo Testamento de Teodoro de Mopsuesta, la enciclopedia bizantina Suida (s.v. à óvoı, § § 3460), el comentario al Mateo, 1:3 de San Jerónimo y la Bibliotheca de Focio (quaest. Anphil.).

48 Neumann, Contra Christianos, p. 94.

49 Por ejemplo Wright, vol. III, p. 314, supone que nunca se acabó y, más adelante, que Cirilo tal vez sólo escribió 20 libros. De la misma opinión con respecto a Cirilo es el editor español (p. 10). Cf. J. QuAsten: Patrology, Spectrum, Utrecht, 1960, 4 vv., vol. 3, p. 129, quien rechaza la hipótesis de Neumann.

50 Cirilo de Alejandría, Adversus Julianum, prol., IV, 17.

51 Libanio, Or. XVIII, 178, op.cit., «atacó los libros que hacen a ese hombre de Palestina dios e hijo de dios, y en una larga y dura polémica demostró que tales honores son pura irrisión y garrulería».

52 Neumann considera que la obra estaba dirigida a Teodoro y otros heréticos, en su Prolegomena, p. 25.

53 Para la crítica de carácter más general de Efrén de Siria, téngase en cuenta el artículo de SIDNEY H. GrIFFITH: «Ephraem the Syrian's Hymns 'Against Julian': Meditations on History and Imperial Power», Vigiliae Christianae, 41/3 (septiembre, 1987), pp. 238-266. Sobre Gregorio Nacianceno, J. GefFCKEN: «Kaiser Julianus und die Streitschriften seiner Gegner», Neue Jahrbücher für das klassische Altertum, Geschichte und deutsche Literatur, 21 (1908), pp. 174-178.

54 Neumann: Prolegomena, pp. 23-31. La noticia de la refutación de Felipe de Sido se encuentra en Sócrates, H.E., VII, 27, mientras la de Teodoro de Mopsuesta en Fragmenta Patrum Graecorum, I, 72 ss..

55 Neumann: Prolegomena, pp. 10-11, en torno a Sozómenes, H.E., V, 18, quien no especifica que este

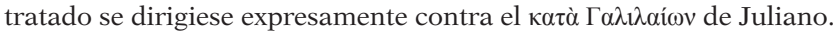


en el Concilio de Éfeso de 431 ni en el edicto de Valentiniano II y Teodosio II de 448 se condenó al Apóstata, y Justiniano, en el año 529, parece haber condenado únicamente a Porfirio ${ }^{56}$. Neumann ha argumentado, sin embargo, que la condena de Teodosio II podría haberse extendido en general a toda obra anticristiana ${ }^{57}$. Sea como fuere, la invectiva de Juliano sobrevivió al menos un siglo y, dado el estado de algunas de sus epís-

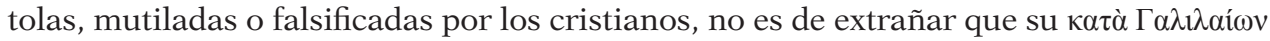
desapareciera de forma natural, tal vez quemada o destruida por sus propietarios ante el miedo o afecto ferviente a la cada vez más fuerte Cristiandad ${ }^{58}$.

\section{La crítica de Juliano al Cristianismo}

Juliano bebe de, al menos, dos fuentes importantes a la hora de emprender su ataque contra la secta de los Galileos: Celso y Porfirio. De la influencia del primero ya se percató Naville ${ }^{59}$, mientras a Porfirio parece referirse Libanio al hablarnos de un «viejo de Tiro» que también habría escrito contra la doctrina cristiana ${ }^{60}$. En nuestro análisis de la crítica juliana al cristianismo intentaremos resaltar aquellos puntos de contacto con las tradiciones paganas precedentes, representadas en las invectivas de Celso y Porfirio, similitudes que, aun despojando de su nunca reclamada originalidad a la obra de Juliano, no hacen sino demostrar que las obras apologéticas precedentes no habían conseguido superar todavía los problemas planteados por el helenismo.

\subsection{La necesidad de salvación}

Para Juliano, como para Celso, la idea de salvación resulta no sólo innecesaria, sino contraria a la misma naturaleza de la divinidad, lo que hace esta concepción de la misma repulsiva a ojos de un pagano:

«De que el conocimiento de dios se da entre los hombres no por aprendizaje, sino por naturaleza, válganos como primera prueba el celo común de todos los hombres, en privado y en público, individual y colectivamente, acerca de lo divino» ${ }^{61}$.

56 Sobre la cuestión, Wright, III, p. 316. Cf. Donaldson, II, p. 303, siguiendo a Neumann, afirma que fue condenado por el edicto de Teodosio II junto a Porfirio.

57 Neumann: Prolegomena, pp. 8 ss., siguiendo a Juan Crisóstomo, II, 339 d.

58 Sobre la censura cristiana a la obra de Juliano, Wright, III, XXVII. Cf. la noticia de Amiano MarceliNo (XXIX, 1, 41 y 2, 4) acerca de las quemas de libros en 371 y la mención de Pablo en Hechos, 19:19 de una quema voluntaria de libros en Éfeso.

59 Naville, p. 84, «Origène répondant à Celse, comme Cyrille répondant à Julien, reprochent à la théorie des dieux nationaux d'être una théorie immorale», en referencia a Orígenes, Contra Celso, V, 25-28, 34 y 39 y Cirilo de Alejandría, Adversus Julianum, IV, p. 116-125 y 134.

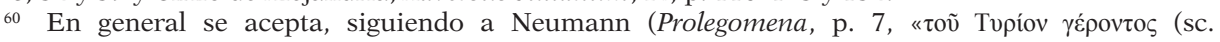
Порфирíov)») que Libanio, en su mencionada oración, se refiere al discípulo de Orígenes. Meredith (pp. 1140 y 1147), sin embargo, pone en duda esta atribución al no ver influencias remarcables de Porfirio. Cf., sin embargo, A. von Harnack: Porphyrius: "Gegen die Christen», 15 Bucher.: Zeugnisse, Fragmente und Referate, en Abhandlungen der königlichen preussischen Akademie der Wissenschaften, Berlin 1916, pp. 3-115; J. Bidez: Vie de Porphyre. Le Philosophie Néo-Platonicien, Georg Olms, Hildesheim 1964, p. 27 (=Juliano, Or. $V, 161$ c). Sobre su relación con Porfirio téngase en cuenta, igualmente, JEFFrey Wayne HaRgIs: Christian Exclusivism and the Formation of Early Anti-Christian Discourse in Celsus, Porphyry, and Julian, Tesis doctoral, Temple University, Filadelfia, 1998.

${ }_{61}$ Juliano, C. Gal., 52 b. Citaremos a partir de la edición castellana, modificándola allí donde creamos conveniente. 
En efecto, el conocimiento de la idea de Dios se encuentra en el hombre de forma natural, y es por ello que la revelación se hace innecesaria ${ }^{62}$. Pero adicionalmente, la divinidad judeo-cristiana interviene en la historia humana de dos formas totalmente contrarias a la idea pagana de Dios: asumiendo un cambio en la divinidad, que debería haber establecido una creación perfecta y equilibrada desde el principio, y preocupándose personal e individualmente por los seres humanos. El resultado de ambas ideas es la encarnación de Dios en Cristo, planteamiento que implica un cambio de categoría inconcebible para una mente helena:

«Sois tan desventurados que ni siquiera guardáis las enseñanzas que os han transmitido los apóstoles y han sido forzadas, empeorándolas y haciéndolas más impías por sus sucesores. Porque ni Pablo se atrevió a decir que Jesús era dios, ni tampoco Mateo, ni Lucas, ni Marcos. [...] Pero este mal tuvo su origen en Juan» ${ }^{63}$.

La crítica de Juliano al evangelista Juan continúa resaltando las contradicciones que provoca esta idea de la divinidad de Jesús en el pensamiento cristiano, pues introduce una concepción politeísta en una religión que, precisamente, se intentaba distanciar del paganismo a través de un monoteísmo reaccionario. En efecto, si como dice Juan (1:18) nadie ha visto jamás a Dios y esto ha sido explicado por Su hijo unigénito (333 c-d), el cual se identifica a su vez con el Verbo, Juliano se pregunta cómo es posible que el evangelista nos diga, inmediatamente después, que «residió entre nosotros y contemplasteis su gloria» (Juan, 1:19). Pero no sólo se contradice a sí mismo Juan, sino que además se opone a la más sagrada ley de Moisés: «Ved que yo soy y que no hay otro dios excepto yo» (Deut., 32:39). Pero los cristianos, al aceptar que Jesús es Dios y que «en el principio fue la palabra y la palabra estaba junto a dios y la palabra era dios» (Juan, 1:1) niegan la tradición judía de un dios único. "¿Cómo concuerda esto con la doctrina de Moisés?», se pregunta Juliano ${ }^{64}$. Comienza aquí el uso retórico del judaísmo que Juliano llevará a cabo para atacar la pretendida originalidad y novedad de la secta de los Galileos ${ }^{65}$.

\subsection{La visión judía de Dios y de la Historia}

Como Celso y Porfirio antes que él, Juliano se percata de que el mensaje cristiano está dirigido a los que carecen de $\pi \alpha \iota \delta$ sía, y no únicamente a los ignorantes en el sentido epistémico del término, sino a aquellas capas más bajas de la sociedad culpables de haber violado las leyes judías:

«Y si hay que decir la verdad, os vanagloriáis de sobrepasar nuestra vulgaridad —esto creo que sucede en todos los pueblos y es muy natural-y creéis adaptar vuestras costumbres a las vidas de los hombres comunes, pastores, publicanos, bailarines y proxenetas. [...] lo que escribe Pablo a los mismos que le oyeron es esto: "No os

62 La misma idea se encuentra en diversos pasajes de Celso, por ejemplo IV, 88; 99. Cf. Jámblico, De mysteriis, I, 3; Salustio, De deis et mundo, I, 1.

63327 a-335 b. Cf. Celso, I, 69; IV, 14; 23; 30; Porfirio, fr. 77. La idea helena de que el hombre es algo demasiado inferior como para merecer la preocupación personal de la divinidad ( $\dot{\alpha} \pi \dot{\theta} \theta \varepsilon 1 \alpha)$ se encuentra en Celso, IV, 85-86.

${ }_{64} 262$ b-c. Cf. 276 c y 306 b, donde según testimonio de CiriLo, Juliano acusaba a los cristianos de tener tres divinidades, tal y como asegura el evangelista Mateo (28:19).

65 El mejor estudio a este respecto lo constituye la tesis doctoral de ARYAY BenNETt FinkelsteIn: Julian among Jews, Christians and "Hellenes" in Antioch: Jewish Practice as a Guide to "Hellenes" and a Goad to Christians, Tesis Doctoral, Harvard University, Harvard, 2011. Sobre las ideas de sacrificio comunes a judíos y griegos, véase pp. 38-83. Sobre el papel de los mártires, que inmediatamente retomará Juliano, pp. 159-194. 
engañéis; ni los idólatras, ni los adúlteros, ni los afeminados, ni los que comparten su lecho con hombres, ni ladrones, ni los ambiciosos, ni los borrachos, ni los injuriosos, ni los saqueadores heredarán el reino de Dios. Y no ignoráis, hermanos, que también vosotros sois así. Pero os habéis purificado, os habéis santificado en nombre de Jesucristo" (1 Cor., 6:9)» ${ }^{66}$.

El resultado de esta carencia de $\pi \alpha 1 \delta$ cía se traduce en una errónea interpretación de la divinidad y de los mitos que a ésta rodean, que son tomados por judíos y cristianos como signos de la revelación de Dios en el mundo, mas como muestra de la imperfección de esta divinidad por los paganos:

«Si el mito no contuviera una interpretación secreta, como yo creo, cada uno de estos relatos estaría lleno de grandes blasfemias acerca de dios. Pues el desconocer que la mujer creada como ayuda será causa de la caída, y, además, el tener envidia de que el hombre tomando del árbol de la vida se convirtiera de mortal en inmortal, es un exceso de envidia y de celos ${ }^{67}$.

Rechazar el carácter fabuloso o alegórico del mito tiene terribles consecuencias desde el punto de vista de la tradición pagana, entre ellas, el hecho de los cristianos caigan en una nueva contradicción, pues desprecian las estatuas a la vez que adoran reliquias ${ }^{68}$, idea esta ofensiva para los paganos y contraria a las palabras del Cristo:

«[...] cuando vosotros a continuación habéis inventado, añadiendo al antiguo cadáver [Cristo] muchos cadáveres recientes [los mártires], ¿quién podría horrorizarse lo suficiente? Todo lo habéis llenado de sepulcros y tumbas, aunque en ninguna parte está dicho entre vosotros que os arrastréis entre las tumbas y las rodeéis de honores. [...] Si, pues, Jesús dijo que los sepulcros están llenos de inmundicia [Mt., 23:27], ¿cómo vosotros invocáis sobre ellos a dios?» ${ }^{69}$.

A diferencia de los $\alpha \dot{\pi} \alpha i ́ \delta \varepsilon v \tau \alpha$, los paganos conocen el verdadero carácter del mito y es por ello que su conocimiento natural del mundo y de la divinidad es superior al cristiano. Para mostrar esto, Juliano expone dos ejemplos paradigmáticos: el relato del Génesis y la Torre de Babel. Comienza formulando la idea judía de la creación y las inexactitudes y deficiencias que ésta tiene: nada nos es dicho con respecto a la creación de los astros situados en el mundo mediático del neoplatonismo, los ángeles, ni tampoco cómo se engendró el espíritu de dios, el abismo, el agua o la noche, conceptos presentes en la antigua tradición helena desde Hesíodo y Homero. Juliano concluye que «según Moisés, dios no es creador de nada incorpóreo, sino ordenador de la materia existente», como demuestra el relato del Génesis ${ }^{70}$. Frente al relato judío, el Timeo de Platón (28 c ss.) ofrece una visión más completa de la creación del Universo y de los dioses intermedios — los astros_-, mostrando al creador de lo incorpóreo y al creador de lo corpóreo como dos divinidades diferenciadas: "si cada una de ellas [las tres razas de mortales]

66238 e; 245 c. Cf. Celso, III, 18; 44; 49; 52; 55; 59; Porf., ffrr. 6, 52.

6794 a. Cf. 75 b; Celso, I, 67. Sobre la función alegórica del mito como envoltorio de la verdad en Juliano, véase el capítulo V de Naville, op.cit. La misma idea se repite en los fragmentos órficos (fr. 3 Bernabé), en Platón (Alcib. II, 147 b) y en el pseudo-Olimpiodoro (in Arist. Cat. prol. 12, 8 Busse).

68 Ep. Frg., 294 c. Cf. Celso, VII, 62; Porf., fr. 76.

69335 b-d. Juliano continuaba, según comentario de Cirilo, citando a Mateo, 8:21-22: «Otro discípulo le dijo: Señor, permíteme ir primero a sepultar a mi padre; pero Jesús le respondió: Sígueme y deja a los muertos sepultar a sus muertos». Cf. Juliano, Ep. XXII, 429 d. Esta idea enlaza con la enfermiza obsesión judeo-cristiana por la resurrección de la carne, a la que veneran a la vez que desprecian. Véase, por ejemplo, Celso, V, 14; VIII, 49. Para la idea de Jesús como un cadáver, Celso, VII, 36.

7096 c-e; 49 a-e. 
existiese gracias a mí, sería totalmente necesario que fuese inmortal ${ }^{71}$. Por ello, el dios de Moisés no puede ser sino una divinidad menor inferior al Helios neoplatónico, una divinidad a la que Juliano caracterizará como un dios de clan ${ }^{72}$.

En segundo lugar, el mito de la confusión de lenguas muestra una vez más la inferioridad del logos judío frente al heleno y la imposibilidad del pueblo elegido por alcanzar un grado de sabiduría que lo sitúe al mismo nivel que los otros pueblos paganos, los

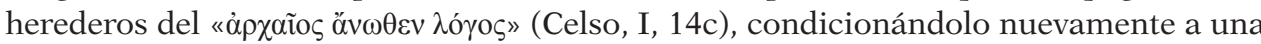
visión falsa y repugnante de la divinidad:

«Moisés dio una causa completamente fabulosa de la falta de semejanza de las lenguas. [...] Pues creo que ante unos hombres ignorantes debe callar el hecho de que, aunque todos los hombres de la tierra entera se valieran de una sola habla y lenguaje, no podrían construir una torre que llegase hasta el cielo. [...] Así, creyendo como auténtico este relato, que es claramente un mito, y sosteniendo la opinión de que dios está asustado de los homicidios de los hombres y que precisamente por eso ha descendido para confundir sus lenguas, ¿todavía os atrevéis a presumir de vuestro conocimiento de dios? $)^{73}$.

El problema de la explicación judía es doble, pues según Juliano no sólo se introduce una visión falsa de la divinidad, controlada por el miedo e incapaz de actuar desde los cielos sobre la tierra: tampoco se consiguen explicar, además, las desigualdades de caracteres, costumbres y leyes de los diferentes pueblos, que para los helenos estaban relacionadas con los dioses tutelares de cada región ${ }^{74}$.

Habiendo fallado en su explicación de la naturaleza del hombre y de la divinidad, Juliano lanza sobre los judíos y los cristianos una nueva acusación: la carencia de sabiduría. Efectivamente, mientras los demás pueblos pueden jactarse de haber descubierto y perfeccionado ciencia y filosofía y de contar entre sus hombres con grandes sabios y políticos, lo mejor que puede ofrecer la tradición judía es la figura del rey Salomón quien, seducido por una mujer, se entregó a la adoración de otros dioses ${ }^{75}$ :

«También los egipcios pueden decir, contando entre ellos nombres de no pocos sabios, que tienen muchos sucesores de Hermes, me refiero a Hermes el tercero que visitó Egipto, y los caldeos y los asirios de Oanes y Belo, y los griegos de innumerables sucesores de Quirón [...] Pero, ¿̇os ha concedido el principio de alguna ciencia o algún saber filosófico?» ${ }^{76}$.

Ni siquiera Jesús puede considerarse una figura remarcable, pues su mayor mérito fue ejercer la magia — aprendida en Egipto— y exorcizar a algunos demonios en las aldeas de Betsaida y Betania:

«Y Jesús, que convenció vuestra peor parte, tiene renombre desde hace poco más de trescientos años, aunque durante el tiempo que vivió no hizo nada digno de fama, a no ser que alguien crea que curar a los lisiados y ciegos y expulsar mediante exorcismos a

7265 d; Platón, Tim., 41 c, dista

73134 d-e; 135 b-d. Cf. Celso, V, 25; 32; VIII, 35.

74131 b; 137 e ss.. La misma idea Platón, Critias, 109 b-c; Leyes, I, 624 a.

75176 a-190 c; 218 b-224 d. Cf. Celso, I, 16 b; VII, 42. Juliano reconoce el carácter antinatural del cristianismo en la idea de que la sabiduría no es dada por el dios hebreo, sino que se encuentra al margen de él, como muestra su recelo en el Jardín del Edén (Gén., 3:22). Cf. 89 b-93 e, respecto al carácter benefactor de la serpiente.

$76 \quad 176$ a-178 a. 
los poseídos por el demonio en las aldeas de Betsaida y Betania sea propio de grandes obras» ${ }^{77}$.

Como consecuencia de todo ello, el cristianismo es entendido como una «invención de unos hombres compuesta por maldad», "no contiene nada divino» y es un «relato monstruoso a la fe de la verdad ${ }^{78}$ que, ante la falta de un sistema moral y gnoseológico coherente, obliga a sus seguidores a recurrir a los textos clásicos paganos, en especial al divino Platón, para alcanzar un grado mínimo de $\pi \alpha 1 \delta \varepsilon i ́ \alpha$ :

«[...] escoged hijos de todos vosotros y preparadlos en vuestras escrituras; si al llegar a la edad varonil alguno parece mejor que los esclavos, pensad que digo tonterías y que tengo la bilis negra. Además, sois tan desgraciados e insensatos que consideráis divinos aquellos tratados por los que nadie podría hacerse más sensato ni más valiente ni mejor que sí mismo; en cambio, aquellos por los que es posible adquirir la valentía, la inteligencia y la justicia, ésos los devolvéis a Satanás y a los que adoran a Satanás» ${ }^{79}$.

Esta carencia de $\pi \alpha 1 \delta \varepsilon i ́ \alpha$ y falsificación de la tradición antigua ${ }^{80}$ desembocan en la visión judía de la historia que ya criticara Celso, un síntoma que en el cristianismo se hace aún más patente con la nueva revelación encarnada en la figura de Jesús ${ }^{81}$. Pues si los hebreos se consideraban el pueblo elegido en el que Dios se mostró desde sus orígenes, el cristianismo no puede ocultar que tras su pretensión de universalidad se encuentra un rechazo a la misma tradición judía, una idea inventada por Pablo, «el más extraordinario mago y embaucador que jamás haya existido en lugar alguno ${ }^{82}$, para quien el dios de Moisés era también el dios de los gentiles ${ }^{83}$. Mas aceptar que el mensaje de Dios se hace realidad en Jesús con un carácter universal plantea cuestiones incómodas al cristianismo de las que irónicamente se mofa Juliano:

«Es justo, pues, preguntar a Pablo, si dios no lo es sólo de los judíos, sino también de los gentiles, ¿por qué envió a los judíos la gracia profética en abundancia, Moisés, la unción y los profetas, y la ley, y las paradojas de sus mitos. [...] Y finalmente también les envió a Jesús; en cambio a nosotros ni profetas, ni unción, ni maestro, ni heraldo que anunciase su amor a la humanidad que algún día, sin duda, también recaería sobre nosotros $»^{84}$.

La visión falsa de la historia y la ignorancia con respecto a la divinidad creadora del Universo llevan a Juliano a concluir que el dios de los judíos y, por ende, el dios cristiano, no es más que un dios de clan, con cualidades humanas y no divinas, inferior a

77191 d. Cf. 213 b; Celso, III, 26-33. Ésta es una acusación plenamente pagana: la lanzaron en su momento Suetonio (Nerón, 16, 2), Tácito (Ann., 15, 44, 3-8) y Plinio el Joven (Epístola X, 96). Cf. MorTON SмIтн: «Pauline Worship as Seen by Pagans», The Harvard Theological Review, 73/1-2 (1980), pp. 241-249; Id.: Jesus the Magician: Charlatan or Son of God, Harper \& Row, San Francisco, 1978, pp. 50 ss. y 180.

$78 \quad 39 \mathrm{a}-\mathrm{b}$.

79230 a. La misma idea, según comentario de CiRILo, se encontraba en 245 d. Es por esta hipocresía y el riesgo a falsificar el discurso tradicional pagano que Juliano prohibió el estudio de los clásicos a los cristianos. Cf. 229 c; Porf., fr. 39.

80 Sobre la expresión, véase Carl Andresen: Logos und Nomos. Die Polemik des Kelsos wider das Christentum, Walter de Gruyter, Berlín 1955, pp. 152-3.

81 Celso, I, 14. La temporalidad del cristianismo será atacada en IV, 7 y por Porfirio en los fragmentos 81-82. Juliano arremete contra Pablo (Rom., 10:4) en 319 d, citando el libro del Éxodo (12:14-15), así como en su Oración V, 170 a.

82100 a. Cf. Porf., fr. 4, en donde también critica las muchas contradicciones en las que entra Pablo continuamente.

83 Rom., 3:29; Gál., 3:28.

84106 c-d. Cf. Celso, IV, 7. 
Helios y, por tanto, un dios intermedio al que corresponde el dominio de lo corpóreo, el cual creó «a su imagen y semejanza» y es, por ello, mortal e impuro ${ }^{85}$.

\subsection{La idea cristiana de Dios y de Jesús}

Como Celso antes que él, Juliano sostiene que el cristianismo es una invención de Pablo y de los evangelistas, pues las ideas de un Dios Padre y de un Mesías hijo del mismo encarnado en un cuerpo humano para sustituir la antigua ley de Moisés no se encuentran en el Antiguo Testamento. En la figura de Jesucristo ninguna profecía ha alcanzado su plenitud, sino que, descontextualizadas, han sido añadidas por los evangelistas para falsificar la tradición y traicionar a sus pretendidos antepasados judíos:

«Pues aquello de "Un profeta entre vosotros levantará el señor dios nuestro de vuestros hermanos como yo; le escucharéis" (Deut., 18:15; Hechos, 3:22) no se refiere precisamente al que nació de María. Y si alguien por vuestra causa lo concediese, Moisés dice que será semejante a él y no a dios, será un profeta con él y procedente de los hombres, pero no de dios. [...] dice Isaías: "La virgen concebirá en su vientre y parirá un hijo" (Isaías, 7:14). Sea esto referido a un dios, sin embargo de ninguna manera ha sido dicho» ${ }^{86}$.

Que el Mesías esperado nada tenía que ver con Jesús fue ya precisado por Celso dos siglos antes (VII, 18) al exponer las contradicciones interiores entre el Antiguo y el Nuevo Testamento en relación a la divinidad y la encarnación del Cristo. Juliano, recuperando esta idea, señala nuevas contradicciones en la doctrina cristiana por pretender derivarse de la tradición judía: así, el Mesías esperado no sólo era un hombre nacido de hombre y semejante a Moisés, sino que debía proceder, además, de Judá, siendo descendiente de la casa real de David. Esto no es posible, concluye Juliano, por varios motivos: si los cristianos hacen a Jesús hijo de Dios siguiendo las palabras de Juan, entonces deberían rechazar el testimonio de Mateo y Lucas ${ }^{87}$, para quienes la profecía mesiánica se cumplía en Jesús por ser descendiente de David a través de José, su padre. De esta forma Juliano no hace sino recoger la opinión herética de su amigo Fotino y del maestro intelectual de éste, Marcelo de Ancira, que negaban la divinidad de Jesús y la coexistencia original de Dios y Logos en el mundo ${ }^{88}$. No debe olvidarse que, con este esbozo de los argumentos de Marcelo de Ancira, Juliano estaba respondiendo discretamente a la obra que Eusebio de Cesarea había escrito como refutación de los postulados de este obispo, Contra Marcellum.

Pero además, que Jesús no es el pretendido Hijo de Dios queda también atestiguado por su continuo comportamiento: lejos de ser el de un héroe en el sentido heleno del término, actúa como un cobarde que no es capaz de soportar el peso de su destino, que necesita de la intervención de un ángel en Getsemaní para fortalecerse (Ẻvıðひúov av̉ióv),

8558 a. Cf. Gén., 1:26. Sobre el carácter intermediario del dios judío en comparación con el demiurgo platónico (Tim., 41 a) véase su Ep. Frg. 292 ss..

86253 c-d; 262 c-d. Cf. Porf. 68. En el fragmento 15 de Neumann, conservado en el comentario latino al libro de Oseas escrito por Jerónimo, Juliano habría atacado el cumplimiento de la profecía de Oseas (11:1) en el Evangelio de Mateo (2:15) como una invención del mismo. Cf. Porf., ffrr. 6, 9 y 15, sobre las mentiras de los evangelistas.

87253 c. Cf. Mat., 1:1-16; Luc., 3:23-38. Juliano habría examinado esta cuestión más detalladamente en su segundo libro, del cual quedan únicamente unos fragmentos. Porfirio hace referencia a los problemas de ambas genealogías en el fragmento 2 .

88 Sócrates, H.E., II, 18-19. Cf. Sozómenes, H.E., IV, 6. 
que no puede evitar su propia muerte aún siendo Dios y que, finalmente, incluso se siente abandonado por su Padre ${ }^{89}$.

\subsection{El cristianismo como anomia y ateísmo}

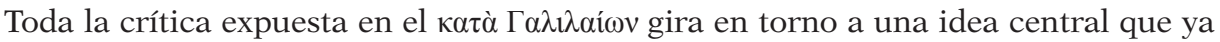
ha salido a relucir en algunos de los pasajes citados: que el cristianismo, más que el judaísmo, es culpable de traición a las leyes y los dioses que toda nación posee, pues

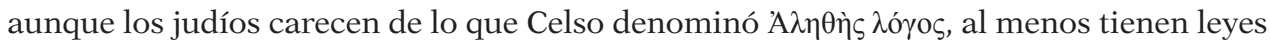
y ejecutan sacrificios como los paganos, pudiendo ser así considerados, cuanto menos, "puros», $\kappa \alpha \theta \alpha \rho i^{90}$. La carencia de sacrificios es, de hecho, lo único que diferenciará a

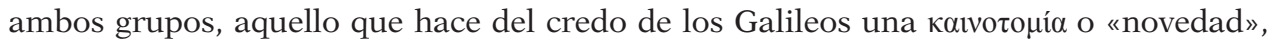
«extrañeza». En efecto, la circuncisión y el sacrificio necesarios para la purificación ritual eran aceptados por Moisés, pero los cristianos los han transvalorado en algo impuro $^{91}$, pecando así contra la misma ley que ellos dicen seguir y siendo calificados, como

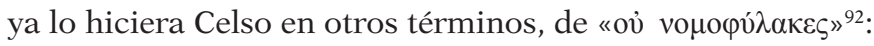

«[...] por qué eligieron sus creencias [las de los hebreos] en lugar de las nuestras y, después, por qué no permanecen en sus propias creencias siquiera, sino que, apostatando, siguieron su propio camino. Aunque no están de acuerdo con ninguna de las bellas e importantes creencias ni de nosotros, los griegos, ni de los hebreos de Moisés ${ }^{93}$ [...] Pues, ¿por qué, separándoos de nosotros, no respetáis la ley de los judíos ni observáis lo que dijo Moisés?» ${ }^{94}$.

Con su idea pueril y tribal de un Dios imperfecto sometido a las emociones humanas e incapaz de salvarse a sí mismo, el cristianismo es calificado en numerosas ocasiones

89 Fragmento 7 (Neumann), conservado en el comentario al Nuevo Testamento de Teodoro de Mopsuesta que recoge parte del libro XII de la obra apologética de Cirilo (Augusto Guida: Teodoro di Mopsuestia, Replica a Giuliano imperatore, Nardini, Florencia, 1994, pp. 193-225). Juliano también encuentra aquí un problema textual, pues si nadie vio la aparición del ángel y Jesús no dio testimonio de la misma a sus discípulos, ¿cómo pudieron recogerla los evangelistas? ¿cómo pudo olvidarla Juan, que se encontraba cerca de Jesús (Mat., 26:37; Mc., 14:33) mas ignora semejante acontecimiento? Sobre esta cuestión y sobre la refutación de Teodoro a este pasaje y su dependencia de Celso (II, 24) o Epifanio (Panarion, 69, 19, 4, Ancoratus, 31, 5, 37 ss.), véase T. BAARDA: «Luke 22:42-77 a. The Emperor Julian as a witness to the text of Luke», Novum Testamentum, XXX, 4 (octubre, 1988), pp. 289-296. Cf. J. GEFFCKEN: Zwei griechische Apologeten, Teubner, Leipzig, 1907, pp. 305 ss.

90238 c. Cf. 291 a ss., según el sumario de Cirilo, los judíos sólo se diferenciarían de los paganos en su monoteísmo y rechazo de la adivinación. Celso también acepta la presencia de Nónos entre los judíos, por ejemplo en V, 25. La ritualidad judía defendida por Juliano como instrumento de crítica a los Galileos

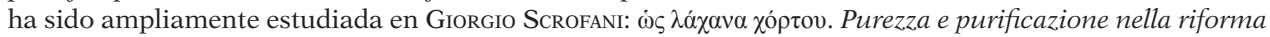
religiosa di Flavio Claudio Giuliano (361-363 d. C.), Tesis doctoral, Pisa, 2007; Id.: "Like Green Herbs": Julian's Understanding of Purity and His Attitude towards Judaism in His Contra Galilaeos », The Journal of Late Antique Religion and Culture, 2 (2008), pp. 1-16.

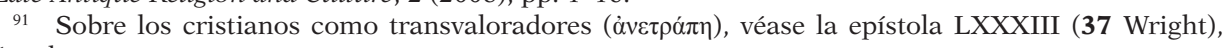
$376 \mathrm{c}-\mathrm{d}$.

92351 b. Juliano, como Porfirio en su fragmento 27, defiende justamente en este momento la circuncisión y, según Cirilo, habría citado las palabras de Jesús en Mateo, 5:17-19 para defender la preservación de la tradición judía. La idea del sacrificio, que aparece en la Ley de Moisés en, por ejemplo, Lev., 16:15, es defendida por Juliano en 299 b.

${ }_{93} 43$ a. En idénticos términos se expresa Celso, calificando a los cristianos de apóstatas judíos (por ejemplo, I, 23). Cf. Porfirio, fr. 1.

94305 d. La idea de anomia puede encontrarse en Celso, III, 3-4; VIII, 24; 55; 75; Porfirio, ffrr. 1, $27-36$ y 88 . 
de ateísmo y culpado de causar, con su rechazo a los sacrificios y su abandono y desprecio de la ley, apatía hacia la religión:

«Viendo, pues, la gran indiferencia que existe entre nosotros hacia los dioses, y desterrado todo el respeto hacia los seres superiores por una impura y grosera molicie, continuamente me lamentaba yo en mi interior de tal situación, ya que he visto que aquellos cuyas mentes se han vuelto a las doctrinas de la religión judia ${ }^{95}$ están tan inflamados que prefieren la muerte por ella y soportar cualquier privación y hambre [...] mientras que nosotros nos comportamos con tal apatía en lo relativo a los dioses que nos olvidamos de nuestras tradiciones ${ }^{96}$.

La actitud de tolerancia de Juliano responde antes a una intención práctica que no a una la simple aceptación de las doctrinas del pueblo hebreo, atacadas y ridiculizadas en numerosas ocasiones: pues si la religión judía, aun formando parte del panteón pagano, puede resultar ridícula o cuanto menos extraña, no alcanza en depravación a la moral que se esconde detrás de los cristianos, contaminadores de la civilización clásica, a la

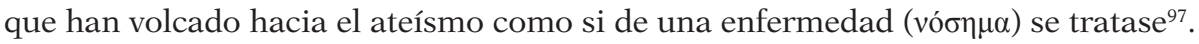

Finalmente Juliano hará hincapié en el carácter subversivo del cristianismo, pues como consecuencia de su ateísmo y, en especial, de su enfermizo rechazo incluso a las propias leyes del Estado, los cristianos son incluso más culpables que los judíos de im-

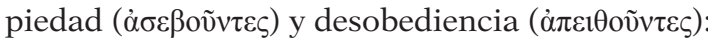

«Sin embargo, han llegado a tal extremo de rabia y de demencia que, como no podían ejercer la tiranía ni lo que se hacían antes entre ellos y después contra nosotros que veneramos a los dioses, exasperados mueven todas las piedras y se atreven a perturbar a la muchedumbre y a provocar revueltas, portándose con impiedad hacia los dioses y con desobediencia a nuestros decretos» ${ }^{98}$.

No es sorprendente que ambas acusaciones remitan a la crítica celsiana estructurada en torno al $\Lambda$ ó $о \varsigma$ y Nó $\mu \circ \varsigma^{99}$, desobediencia a la tradición antigua entregada a los hombres por los dioses y a las leyes que, a partir de las mismas, mantienen unida la polis. Es por ello que el cristianismo es concebido una vez más como una «enseñanza revolucionaria» ${ }^{100}$ que ataca la harmonía del Imperio y causa ateísmo y rechazo de las mores maiorum de las que depende la ciudad. Como revolucionarios, los cristianos se embriagan en la venganza, primero contra sus propios antepasados, el pueblo judío y, después, contra ellos mismos, produciendo escisiones en su misma secta a causa de su odio humani generis:

«Pues de su [Jesús] pureza ni habéis guardado recuerdo, en cambio, imitáis la cólera y la crueldad de los judíos volcando los templos y los altares, y habéis degollado no sólo a los que de los nuestros permanecían en las creencias tradicionales, sino también, de entre los que padecen vuestro mismo error, a los heréticos [los arrianos] que no plañen el cadáver [Jesús] de la misma manera que vosotros» ${ }^{101}$.

95 Restituimos aquí el texto sugerido por Hertlein, ausente en la edición española.

$96 \quad 453 \mathrm{c}-\mathrm{d}$.

97 Ep. XXII (84), 429 d; 430 b; (89b), 288 a; Misopogon, 346 b. Cf. Ep. XX (89a), 454 b; XXXVI (72), 424 a. «Enfermedad» es entendida por Juliano como vicio o desorden también social y, por tanto, tal término resalta el carácter revolucionario cristiano. Los paréntesis en números arábigos indican la numeración en la edición castellana y francesa.

98 Ep. XLI (114), 436 b, fechada el 1 de agosto de 362.

99 ANDRESEN, p. 208.

100 Ep. XLVII (111), 432 d. Cf. Porf., fr. 1.

101206 a. Cf. 83 c; Celso, I, 1; 3; III, 5. 


\section{CONCLUSIÓN}

En junio del año 363, a pesar de los fatigados esfuerzos de su médico personal Oribasio de Pérgamo, una fatal herida en batalla acabó con la vida de Juliano Emperador, poniendo punto final a la campaña que éste había iniciado en Persia — su sucesor, el oficial cristiano Flavio Claudio Joviano, fue incapaz de llevar a sus tropas a la victoriay al breve renacer que el paganismo había experimentado durante su efímero reinado. Este nuevo triunfo transformó en leyenda la muerte del Apóstata, convirtiéndose en ocasional ejemplo de victoria sobre las huestes del satanismo ${ }^{102}$. Muchas han sido las «muertes» definitivas impuestas al paganismo, desde el canto recogido por Plutarco y confirmado por Eusebio sobre su abandono en tiempos de Tiberio hasta el asesinato salvífico del Apóstata Juliano que describe Sozómenes ${ }^{103}$, pero lo cierto es que, aun a pesar de la pervivencia de las prácticas paganas dentro y fuera de la cristiandad tan acertadamente descritas por Cameron en su más reciente estudio, la victoria filosófico-teológica del cristianismo sobre el helenismo fue un hecho percibido claramente por Teodoreto, quien recoge las palabras apócrifas del Apóstata en su lecho de muerte: «Has vencido, Galileo» ${ }^{104}$.

A la carencia de originalidad de la crítica juliana al cristianismo, caracterizada por Bolton como «not very impressive or intelectually stimulating ${ }^{105}$, debe contraponerse la naturaleza transmisora de sus escritos: su obra no es sino una respuesta a los recientes textos galileos - leídos por Juliano gracias a la biblioteca de Jorge de Capadocia- que pretenden refutar las invectivas de Celso y, en especial, de Porfirio. La respuesta de Juliano, silenciosa, es que la crítica de sus predecesores sigue todavía viva y actual pues no ha sido adecuadamente contestada, y es por ello que no puede sino recuperar los argumentos neoplatónicos de sus maestros intelectuales. No obstante, debe destacarse su singularidad en el uso instrumental y retórico que realizará del pueblo judío, ora criticando su falta de conocimiento de la historia y de la divinidad, ora usándolo como

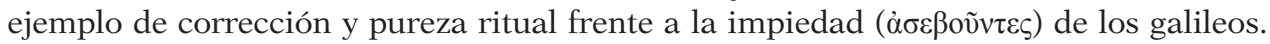
Con este término, diferenciándose de Porfirio, Juliano pretende a su vez caracterizar al nuevo pueblo elegido como una simple secta rebelde del judaísmo que ha dado la espalda a las más antiguas tradiciones de sus padres.

La importancia histórica de la obra anticristiana de Juliano, así como su actualidad, se halla en el modo en que él, como sus predecesores, se enfrenta a los textos evangélicos: a diferencia de la mitología pagana, una vez más, los textos galileos no son simples testimonios de fe o tratados filosófico-teológicos sujetos a una determinada interpretación, sino relatos pretendidamente reales que deben ser leídos ad pedem litterae. La respuesta de sus detractores, que asume igualmente una lectura literal de los Evangelios,

102 Sobre las diversas leyendas que surgieron en torno al supuesto asesino de Juliano — un demonio, un santo o un cristiano-, véase Norman H. Baynes: «The Death of Julian the Apostate in a Christian Legend», The Journal of Roman Studies, 27 (1937), pp. 22-29; Irfan SHaHî: Byzantium and the Arabs in the Fourth Century, Dumbarton Oaks, Washington, 1984, pp. 125 ss.

103 Respectivamente, Plutarco, De Defectu Oraculorum, 17, 2; Eusebio, P.E., V, 17; Sozómenes, H.E., VI, 2.

104 Teodoreto, H.E., III, 20. Sobre los usos literarios de esta anécdota, véase H. C. TEITLER: «Julian's Death-bed and Literary Convention», en Caroline Kroon y DaniëL den Hengst: Ultima Aetas Time, Tense, and Transience in the Ancient World: Studies in Honour of Jan den Boeft, Vrije Universiteit University Press, Amsterdam, 2000, pp. 71 ss.

105 Charles A. Bolton: "The Emperor Julian against "Hissing Christians" ", The Harvard Theological Review, 61/3 (1968), pp. 496-497, p. 496. 
no hace sino reafirmar la posición juliana de que la crítica helena y neoplatónica al cristianismo permanece sin respuesta efectiva para sus críticos, como confirman, tras casi dos milenios, las semejanzas entre los argumentos expuestos por Celso, Porfirio y Juliano, por un lado, y el último Christenhasser, Friedrich Nietzsche ${ }^{106}$.

Nankai University (Tianjin, China)

César Guarde Paz

cguardpa7@alumnes.ub.edu

[Artículo aprobado para publicación en diciembre de 2012]

106 Así lo expresaba el discípulo de Heidegger, KARL LöwITH: «If one compares the arguments of Nietzsche with those of Celsus and Porphyry, it is not difficult to see how little has been added to the ancient arguments [...] To Celsus as well as to Nietzsche the Christian faith is crude and absurd. It destroys the rationality of the cosmos by an arbitrary initiative» (Meaning in History: The Theological Implications of the Philosophy of History, University of Chicago Press, Londres, 1957, p. 220; cf. Id.: Nietzsche's Philosophy of the Eternal Recurrence of the Same, University of California Press, California, 1997, pp. 108-121). Sobre las similitudes entre Nietzsche y Juliano, véase JAY BREGMAN: «The Roles of Apollo and Dionysus in Nietzsche's Birth of Tragedy and in Emperor Julian's Theology», en John Finamore y Robert Berchman: Metaphysical Patters in Platonism, University Press of the South, Nueva Orleans, 2007, pp. 103-120. Aunque se ha sugerido lo contrario, Nietzsche pudo haber conocido las invectivas de Celso, a quien parece citar en su Genealogía de la Moral, GM, I:14, en KGW, VI2, p. 296, ll. 4-7 (cf. Celso, I, 1). Menos concluyente resulta la cita directa de la obra de Orígenes, c. Celsum, VI, 42, que corresponde al fr. 80 de Heráclito, aquí citado por Nietzsche en alemán a través de la traducción de su maestro en Pforta, Heinze (Los Filósofos Preplatónicos, § 10, en KGW, II4, p. 272, 1l. 6-8; MAX HeInZE: Die Lehre von Logos in der griechischen Philosophie, Berlín, 1872, p. 22). 